\title{
Cultured meat as halalan toyyiban food: a maqasid review in the preservation of life (hifz an-nafs)
}

\author{
${ }^{1}$ Reza Adnan, M.R.A, ${ }^{1}$ Mohd Fadzil, S.D.N, ${ }^{2}$ Baharuddin, A.S. and ${ }^{1, *}$ Wan Harun, M.A \\ ${ }^{1}$ School of Humanities, Universiti Sains Malaysia (USM), 11800 Pulau Pinang, Malaysia \\ ${ }^{2}$ Faculty of Syariah and Law, Universiti Sains Islam Malaysia (USIM), Bandar Baru Nilai, 71800, Nilai, \\ Negeri Sembilan, Malaysia
}

\begin{abstract}
Article history:
Received: 5 March 2021

Received in revised form: 17 April 2021

Accepted: 28 June 2021

Available Online: 3 October 2021
\end{abstract}

\section{Keywords:}

Cultured meat,

Halalan toyyiban,

Maqasid al-Shariah,

Hifz An-Nafs,

Environmental pollution,

Human health

DOI:

https://doi.org/10.26656/fr.2017.5(5).161

\begin{abstract}
It is expected that the global population, which is currently 7.3 billion, will exceed 9 billion by the year 2050. Therefore, the Food and Agriculture Organization (FAO) has estimated that $70 \%$ more food will be needed in 2050 in order to meet the needs of the increasing human population. This is a massive test due to the limiting resources and arable land. Cultured meat is designated as one of the safe options among the alternatives by its proponents for the public who wish to be environmentally friendly but oppose altering their diets. This study proposed to achieve the maqasid review on the cultured meat product. This study used a qualitative method whereby references related to maqasid al-shariah and cultured meat and its rulings in Islamic perspectives were used to obtain further information, including the area of halal food because it is under the same circumstance. Halal cultured meat can be concluded as a new invention of food technology that complies with maqasid al-shariah in terms of protection of life (hifz annafs). Thus, it is suggested that Muslims must involve the technology of the production of cultured meat or necessary action be taken so that any haram (unlawful) element should be avoided in producing halal cultured meat.
\end{abstract}

\section{Introduction}

It is expected that the global population, which is currently 7.3 billion, will exceed 9 billion by the year 2050. Therefore, the Food and Agriculture Organization (FAO) (2006) has estimated that $70 \%$ more food will be needed in 2050 in order to meet the needs of the increasing human population. This is a massive test due to the limiting resources and arable land. Even if meat consumption in advanced countries is declining, global consumption will continue to rise because consumers are usually reluctant to lower their consumption of protein, especially meat, particularly in developing nations (Tobler, 2011). These countries are becoming more advance than they used to be, making them search for additional extravagant foods derived from meat and dairy products.

Livestock systems are capable of monitoring the world's food and nutrition protection (Willett et al., 2019). Animal agriculture should produce greater amounts of high-quality and sustainable beef, eggs and milk through environmentally safe, socially responsible and economically viable processing processes (Scollan et al., 2011). Regardless of the immense variety of financial, environmental, cultural and social services offered by livestock farming at state, regional and global levels (Ryschawy et al., 2019), a higher portion of livestock currently breeds under the factory farming standard. Factory farming focuses predominantly on the productivity of the amount of dairy or meat product instead of using other resources and prioritising impacts. For example, environmental impacts, climate changes, controlled usage of antibiotics, animal wellbeing or biodiversity (Steinfeld et al., 2006), despite a reduced exposure to greenhouse gases (GHG) and water used than comprehensive agriculture. As a result, more effective protein processing methods are being built to feed the increasing global population while facing global issues like environmental and animal welfare problems. Thus, the production of cultured meat can be one of the answers to counter environmental pollution.

Cultured meat is designated as one of the safe options among the alternatives by its proponents for the public who wish to be environmentally friendly but oppose altering their diets. The purpose of the cultured meat process is to recreate with a few cells, the complex 
structure of the muscles of livestock. A biopsy from a living animal is taken. The muscle cutting will liberate stem cells that are capable of reproducing but can also turn themselves into multiple kinds of cells, including meats and fats cells.

At the simplest point, cultured meat is lab-produced meat that is developed without any intervention of the animal and its natural growth processes. Unlike typical or orthodox way based on plants or other substitutes to meat (van der Weele et al., 2019). It is built from muscle cells and similar to the post-mortem skeletal muscle in species such as poultry, mammal, and marine that were historically bred for their edible tissues. Technically, cultured meat tissue is non-meat (Hocquette, 2016) as the latter is also a post-mortem biochemistry product. To support the point stated above, Thorrez and Vandenburgh (2019) have stressed that numerous obstacles may stay with the meat functional engineering include whether carrying important nutrients such as vitamins B, D, creatine, minerals, carnosine by cellbased meat can be as efficient as conventional meat.

There are several considerations that drive scientists to generate culture meat, for instance, the increase in the population of the world, the rise in demand for meat resulting from prosperity, environmental destruction, animal protection, cost reduction, especially in the areas of processing, breeding and transporting, and also health issues (Baharuddin et al., 2020).

Cultured meat should be considered safe to consume as scientists can measure the dietary value for human needs by means of the meat culture approach. This makes a better and safer alternative for cultured meat relative to as there is a common link between meat intake and an elevated risk of many diseases like heart failure, diabetes and cancer, traditional meat (Larsson and Wolk, 2006). It is possible to monitor the nutritional quality of cultured meat by changing the composites used in the manufacturing medium for the substance and fat. It is also possible to regulate the proportion of saturated fatty acids to poly-unsaturated fatty acids. Other types of fats, such as omega-3s, will replace saturated fats (Eelen, 1998). Thus, the nutrient of cultured meat can be adjusted according to the condition of human health.

To enter the halal market, cultivated meat should comply with Halal standards and requirements. Moreover, it is necessary to comply with the Halal law, and ignoring the vast possibility of the Halal market could result in a significant loss to the industry player (Baharuddin et al., 2020).

Muslims were obligated to consume and use only hygienic, healthy, and nutritious products (Fischer, 2011;
Ambali and Bakar, 2013). The key principle regarding dietary practice is that all foods are halal except for pork and its by-products, carcasses, animals that were slaughtered wrongly, animals slaughtered on behalf of anyone other than Allah, carnivorous organisms and birds of prey. Also, intoxicative alcohol of all types such as wine, whisky, malt and others, poisonous plants and aquatic animals, by-products of blood and semen, and all foods that have been contaminated with any of the ingredients above are considered as Haram (AlQaradawi, 2013). Nevertheless, some recent studies indicated that the concept of halal is a contemporary and profane cultural phenomenon and not just a religious argument (Wilson and Liu, 2011). Wilson and Liu (2011) have suggested that various national and cultural backgrounds of Muslims globally will differ the interpretations of their halal practices. They consider halal as an environment where risk avoidance impacts perceptual, affective, and conative decision-making habits. These contribute to the cultural lens of Muslim consumers and Islam (Wilson and Liu, 2011).

In addition, to ensure the quality and hygiene of halal food, Malaysia Halal standards were invented. The role of authority is very important, which act as a caretaker of Muslims need halal and quality food products. The halal standard will also help to sustain social stability, as Muslims are the second-largest religion in the world. Muslim population, particularly in Malaysia, will safely consume halal food products on the market by taking halal issues seriously. (Kashim et al., 2020). Halalan toyyiban is an obligation in Muslims daily dietary practices as it was stated in the Quran and Sunnah, the two main references in Islamic law (Fadzli et al., 2021).

As of today, there are still no direct fatwa regarding the process or the consumption of cultured meat. But several guidelines must be followed before the cultured meat can be considered halal.

Basically, cultured meat is a new concept that has never once been discussed and debated by previous scholars (fuqaha'). Thus, any ijtihad made by the present Islamic scholars must seek and provide answers to all technologies presented, whether it suits the requirements of Islamic law.

Thus, in order to ensure the cultured meat complies with halal principles, the cells taken to produce cultured meat must be derived from halal sources, which is from a halal slaughtered animal as stated in the Quran and hadiths. 


\section{Materials and methods}

This study proposed to achieve the maqasid review on the cultured meat products. Although there are several kinds of research on the ruling of cultured meat in Islamic view, this study felt that a review of maqasid preservation of life (hifz an-nafs) on cultured meat should be made in order to gain more understanding on this field of research. This study extended the works from other field's researchers. This study analysed the maqasid on the preservation of life (hfiz an-nafs) within the area of cultured meat. Identifying the maqasid review process on halal cultured meat in this study used a qualitative method. Secondary data related to maqasid al -shariah and cultured meat and its rulings in Islamic perspectives were used to obtain further information including the area of halal food because it is under the same circumstance. This research is limited to review the context of protection of life (hifz an-nafs) on cultured meat and halal determination factor of cultured meat from the view of the cell taken source.

\section{Results and discussion}

Through this article, the finding will be shown in two main points which are the halal status of cultured meat and also the maqasid review on cultured meat base on the concept of preservation of life (hifz an-nafs).

\subsection{Halal status of cultured meat}

Cultured meat is a new invention in food engineering; thus, renowned Islamic scholars such as Shafi'ei, Hanbali, Hanafi and Maliki do not discuss in focus the status of cultured meat. Thus, contemporary jurists must make ijtihad that provides answers for the issue of whether it complies with of Islamic law or not.

In deciding the halal status of a specific foodstuff, there are many factors that need to be considered. One of them is it depends on how it has been processed and where it originated from. For instance, any pig product is considered haram (unlawful) since it contains a prohibited ingredient. Similarly, any meat of an animal that has not been slaughtered according to Shari'ah is also considered haram (unlawful) as mentioned in a Quranic verse as below:

" $\{\mathrm{O}$ you, who have believed, eat from the good things which We have provided for you, and be thankful to Allah if it is He alone Whom you worship. Indeed, what He has only forbidden to you is the flesh of dead animals and blood and the flesh of swine, and that which has been dedicated to other than Allah. But whoever is forced [by necessity], neither desiring [it] nor transgressing [it's limit], there is no sin upon him. Indeed, Allah is Ever-Forgiving and Ever Merciful.\}"
In the cultured meat case, in order to be classified as halal, the stem cells must be taken from properly slaughtered animals. If the stem cell source was seized within alive animals, then the cultured meat is considered haram and shall not be consumed. Figure 1 below shows the determine factors of cultured meat halal status.

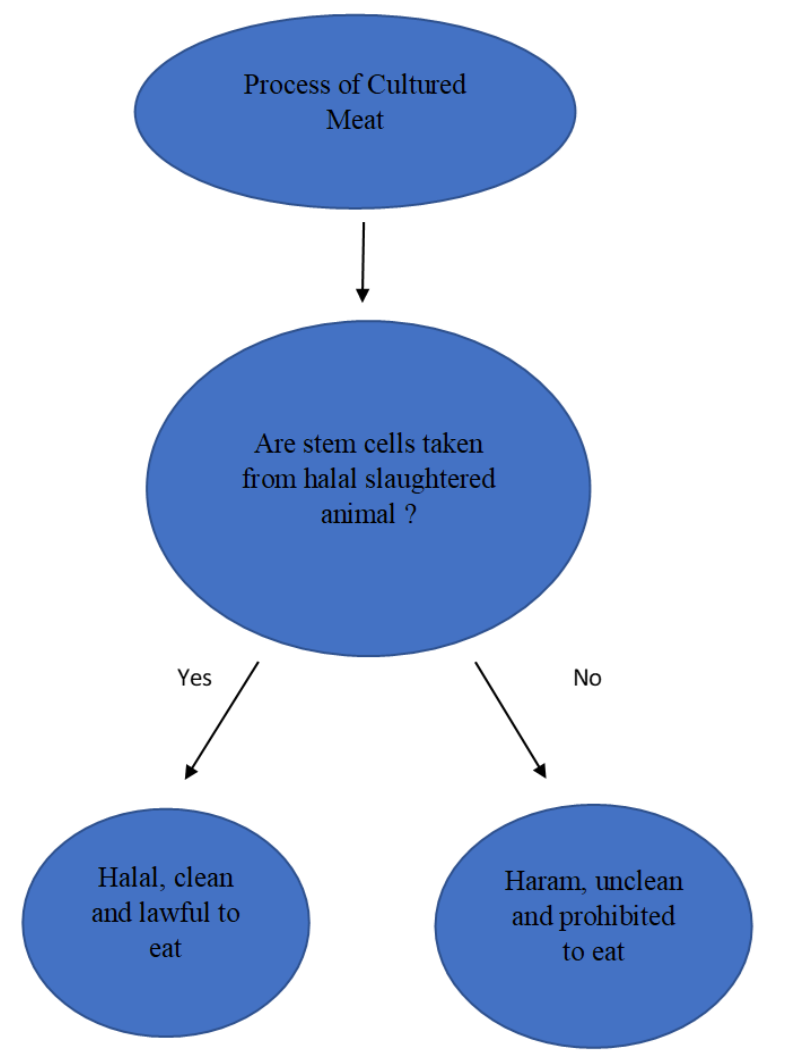

Figure 1. Determine factors of cultured meat halal status (from the view of taken cell source)

3.2 Maqasid review on cultured meat in preservation of life (hifz an-nafs)

'Maqasid' in literal Arabic language means objectives or purposes. Therefore, maqasid al-shari'ah can be defined as the objectives of shari'ah (ibn Ashur, 2006). Therefore, Islamic researchers refer to the accordance of al-Quran and al-Sunnah. It consists of five important fundamental values that is a necessity for every human in this world to live calmly.

Besides, maqașid is meant to protect mașlahah and against mafsadah. It is split into three division which are maqasid daruriyyat, maqasid hajiyyat and maqasid tahsiniyyat. The foundation of this division made maqasid efficient itself. Thus, the significance of maqașid becomes a tool for mujtahid (authoritative interpreter of Islamic law) to review the new ruling in Islamic practices, which is relevant to darurat; therefore, ijtihad (independent reasoning) issued does not discriminate against the objective of the Islamic law. 
(Salhath, 2012; Baharuddin, Wan Ismail, Abdul Mutalib et al., 2019).

Maqasid al-shariah approach helps to protect the interest of people in this and the next world and prevent them from suffering harm (Baharuddin, Ahmad, Ismail et al., 2019). The shariah's primary purpose is to improve the wellbeing of all human beings, which is to safeguard faith (din), their human selves (nafs), their intellect (aql), their posterity (nasl) and their wealth $(\mathrm{mal})$. It ensures that the public interest is served by what allows the protection of these five objectives and is therefore desirable.

Islam forbid the consumption or production of harmful goods and products. Thus, in the preservation of life context, cultured meat is not permitted if it contains any harmful ingredient such as poison or hazardous item.

Say, "I do not find within that which was revealed to me [anything] forbidden to one who would eat it unless it is a dead animal or blood spilt out or the flesh of swine for indeed, it is impure - or it is [that slaughtered in] disobedience, dedicated to other than Allah. But whoever is forced [by necessity], neither desiring [it] nor transgressing [its limit], then indeed, your Lord is Forgiving and Merciful."

(Al-An'am:145)

In term of daruriyyat, in order to protect human life, it is permissible to consume, prohibited food for the sake of saving human life subject to specific condition and situation. The Qur'anic verse states that eating certain kinds of non-permissible food are allowed during darurah situations. As mentioned by al-Ghazali (n.d) in Syifa'al-Ghalil, scholars interpret to the extent of very unlawful food. In the case of cultured meat, one can eat cultured meat that contains unlawful ingredient in darurat condition.

Next, hajiyyat, or also known as complementary benefits, is characterised as benefits that aim to soothe hardship in cases where such severity does not cause a threat to the very survival of normal orders. It is intended to remove the challenges and obstacles that can lead to hardship. If this maslahah does not met, troubles and hardships may follow. As stated in the brief explanation of cultured meat, its invention is to overcome the problem of shortage of livestock in future; thus, the production of halal cultured meat is in accordance with maqasid al-shariah, preservation of life (hifz an-nafs).

Lastly, tahsiniyyat, which is the maslahah of customs and elements of the moral prefecture. If it is not fulfilled, then life will be bad but does not cause difficulties for humans. The production of halal cultured meat should emphasize the aspect of hygiene by following halal standards that provide by the authorities and would be better if the production complies with Hazard Analysis Critical Control Point (HACCP), this is to maintain the hygiene and the quality of halal cultured meat is in the best condition. The bad condition and quality of cultured meat could affect the condition of human health due to the existence of bacteria and other microbes that could be harmful to human health.

Thus, cultured meat can be classifciations into three classes of maqasid al-shariah. The classifications are due to certain situations and conditions as explained in Table 1. Table 1 shows the evaluation of maqasid alshariah (hifz an-nafs) on cultured meat.

\section{Conclusion}

Sciences and technology provide a variety of improvement to ease daily human life; this also occurs in food products. One of the newest food technologies is the invention of cultured meat. Muslim contemporary scholars should be more progressives in providing ijtihad and fatwa so that Muslims could be more aware of its halal status. Furthermore, Halal cultured meat can be concluded as complies with maqasid al-shariah in term

Table 1. Evaluation of maqasid al-shariah (hifz an-nafs) on cultured meat

Classification of maqasid al-shariah
in terms of hifz an-nafs

in terms of hifz an-nafs
Situations and Conditions

1. If there is no halal food available, it is permissible to consume non-halal cultured meat to preserve life subject to darurat condition.

Daruriyyat

2. Cultured meat could be classified as daruriyyah at non-arable land. It will be the main source of protein in the area that is not suitable for agriculture activities.

1. At the warzone, cultured meat will act as an alternative protein supply to solve the problem of insufficient food among the soldiers.

Hajiyyat
2. As a product that could counter the estimated shortage $(70 \%)$ of food product in 2050 (an estimated 9 billion of the world population)

3. Cultured meat could be needed as a protein source at the refugee camp that has an insufficient food supply.

Cultured meat act as a better and safer alternative as it lowered the risk of many diseases like heart failure, diabetes and cancer by considering the nutritional quality of the meat. 
of protection of life (hifz an-nafs). Thus, it is strongly suggested that Muslims must be at the forefront of cultured meat development in order to ensure the meat produced is free of non-halal elements.

\section{Conflict of interest}

The authors declare that they have no known conflict of interest or personal relationships which have, or could be perceived to have, influenced the work reported in this article.

\section{Acknowledgement}

This article was supported by the Ministry of Higher Education Malaysia as part of the Fundamental Research Grant Scheme with project code: FRGS/1/2018/SSI03/ $\mathrm{USM} / 03 / 1$

\section{References}

Al-Qaradawi, Y. (2013). The Lawful and the Prohibited in Islam: الحلال والحرام في الإسلام.Kuala Lumpur: Islamic Book Trust.

Baharuddin, A.S., Wan Ismail, W.A.F., Abdul Mutalib, L., Ahmad, M.H., Razak, R., Saharudin, N.S. and Abdull Rahim, M.A. (2019). An Appraisal of Maqāsid Al-Shari'ah Classic and Recent Literature: Systematic Analysis. Library of Philosophy and Practice, 3730.

Baharuddin, A.S., Ahmad, M.H., Ismail, W.A.F.W., Mutalib, L.A. and Harun, M.A.W. (2019). Catalysing global peace through the strengthening of forensic science application in Sharī 'Ah Law. AlShajarah: Journal of the International Institute of Islamic Thought and Civilization (ISTAC), 2019, 77103.

Baharuddin, A.S., Ghazali, M.I.M., Harun, M.A.W., Mutalib, L.A., Ismail, W.A.F.W., Shaarani, S.M., Alauddin, M.S. and Razali, M.F.A. (2020). ThreeDimensional (3D) Printed Halal Meat: Do We Need A New Regulatory Framework?. INSLA EProceedings, 3(1), 438-449.

FAO. (2006). Livestock's long shadow: environmental issues and options. Rome: FAO.

Fadzli, S.D.N.M., Harun, M.A.W., Baharuddin, A.S. and Adnan, M.R.A.R. (2021). Produk Makanan Ubah Suai Genetik (GMF) Dalam Perspektif Konsep Halalan Toyyiban Berdasarkan Penilaian Maqasid Hifz An Nafs. Malaysian Journal of Syariah and Law, 9(1), 73-85. [In Bahasa Malaysia].

Fischer, J. (2011). The Halal frontier: Muslim consumers in a globalized market. Switzerland: Springer. https://doi.org/10.1057/9780230119789
Ibn Ashur, M.A.T. (2006). Ibn Ashur treatise on maqasid al-shari'ah. Washington, D.C., USA: International Institute of Islamic Thought. https://doi.org/10.2307/ j.ctvkc673b

Kashim, M.I.A.M., Noor, A.Y.M., Ab Rahman, Z. and Muhd, N.I. (2020). Animal DNA and Halal Status of Chocolate Products in Malaysia. Journal of Critical Reviews, 7(5), 1009-1016.

Larsson, S.C. and Wolk, A. (2006). Meat consumption and risk of colorectal cancer: a meta-analysis of prospective studies. International Journal of Cancer, 119(11), 2657-2664. https:// doi.org/10.1002/ijc.22170

Salhath, R. (2012) al-Hukm al-Shariy Baina Manhaj alIstinbāt wa Fiqh al-Tanzil, Syria: Muassasah Dar alNawadi

Ryschawy, J., Dumont, B., Therond, O., Donnars, C., Hendrickson, J., Benoit, M. and Duru, M. (2019). An integrated graphical tool for analysing impacts and services provided by livestock farming. Animal, 13 (8), 1760-1772. https://doi.org/10.1017/ S1751731119000351

Scollan, N.D., Greenwood, P.L., Newbold, C.J., Yanez Ruiz, D.R., Shingfield, K.J. and Wallace, R.J. (2011). Future research priorities for animal production in a changing world. Animal Product Science 51(1), 1-5. https://doi.org/10.1071/AN10051

Steinfeld, H., Gerber, P., Wassenaar, T., Castel, V., Rosales, M. and de Haan, C. (2006). Livestock's long shadow: Environmental issues and options. Rome: Food and Agriculture Organization of the United Nations.

Thorrez, L. and Vandenburgh, H. (2019). Challenges in the quest for 'clean meat'. Nature Biotechnology, 37 (3), 215-216. https://doi.org/10.1038/s41587-0190043-0

Tobler, C., Visschers, V.H. and Siegrist, M. (2011). Eating green. Consumers' willingness to adopt ecological food consumption behaviors. Appetite, 57 (3), 674-682. https://doi.org/10.1016/ j.appet.2011.08.010

Van Der Weele, C., Feindt, P., van der Goot, A.J., van Mierlo, B. and van Boekel, M. (2019). Meat alternatives: an integrative comparison. Trends in Food Science and Technology, 88, 505-512. https:// doi.org/10.1016/j.tifs.2019.04.018

Willett, W., Rockström, J., Loken, B., Springmann, M., Lang, T., Vermeulen, S., Garnett, S., Tilman, D., DeClerck, F., Wood, A., Jonell, M., Clark, M., Gordon, L.J., Fanzo, J., Hawkes, C., Zurayk, R., Rivera, J.A., Vries, W.D., Sibanda, L.M., Afshin, A., Chaudhary, A., Herrero, M., Agustina, R., Branca, 
F., Lartey, A., Fan, S., Crona, B., Fox, E., Bignet, V., Troell, M., Lindahl, T., Singh, S., Cornell, S.E., Reddy, S., Narain, S., Nishatar, S. and Murray, C. J. (2019). Food in the Anthropocene: the EAT-Lancet Commission on healthy diets from sustainable food systems. The Lancet, 393(10170), 447-492. https:// doi.org/10.1016/S0140-6736(18)31788-4

Wilson, J.A. and Liu, J. (2011). The challenges of Islamic branding: navigating emotions and halal. Journal of Islamic Marketing, 2(1), 28-42. https://doi.org/10.1108/17590831111115222 